\title{
Cohabitation and Christian faith
}

\begin{abstract}
Author:
Francois P. Möller ${ }^{1}$

Affiliation:

${ }^{1}$ Auckland Park Theological Seminary, Auckland Park, South Africa

Correspondence to:

Francois Möller

Email:

francois.moller49@gmail.com

Postal address:

Private Bag X6001,

Potchefstroom,

2520, South Africa

\section{Dates:}

Received: 16 March 2011

Accepted: 17 Oct. 2011

Published: 28 Feb. 2013

How to cite this article:

Möller, F.P., 2013,

'Cohabitation and Christian faith', In die Skriflig/In Luce Verbi, 47(1), 9 pages. http:// dx.doi.org/10.4102/ids. v47i1.79
\end{abstract}

\section{Copyright:}

(C) 2013. The Authors.

Licensee: AOSIS OpenJournals. This work

is licensed under the Creative Commons Attribution License.
The habit of cohabitation is an increasing phenomenon in our society. It is usually seen as a trial marriage to test the compatibility of the partners involved. Although it has become socially acceptable, it contradicts the most fundamental doctrines of the Christian faith. The question is therefore whether cohabitation could indeed be accepted as a trial marriage or even a marriage that differs in name only. Unfortunately most Christians find it difficult to give an answer to this question because they are not properly informed of the biblical view in this regard. Biblical direction is therefore important. This is done from a dogmatic-ethical perspective. The emphasis is not on counselling or the exegesis of certain scriptures as such, but on relevant biblical principles concerning this topic. This does not mean that scriptural passages could be ignored. It stands to reason that biblical principles should be derived from specific Scriptures, and the aim is to deal with these Scriptures in a responsible way. This means, inter alia, that context and historical background are important. In doing so, these principles will not only be identified as guidelines in dealing with the habit of cohabitation, but also as principles that make sense in applying them. This was done by identifying some of the problems involved in cohabitation, followed by a biblical perspective of that which constitutes marriage over against cohabitation.

Saambly en die Christelike geloof. Die gebruik van ongetroudes om saam te bly, is ' $n$ verskynsel wat in die samelewing toeneem. Dit word gewoonlik as 'n toetshuwelik beskou om te bepaal of die paartiie regtig by mekaar pas met die oog op 'n huwelik. Alhoewel dit 'n sosiaal-aanvaarde praktyk geword het, staan dit lynreg teenoor die mees fundamentele leerstellings van die Christelike geloof. Die vraag is daarom of saambly inderdaad as ' $n$ toetshuwelik aanvaar kan word of enigsins as 'n huwelik beskou kan word - een wat net anders genoem word. Ongelukkig is dit vir die meeste Christene moeilik om hierdie vraag te beantwoord omdat hulle nie behoorlik ingelig is oor wat die bybelse siening in hierdie verband nie. Bybelse riglyne oor hierdie onderwerp is dus baie noodsaaklik. In hierdie artikel word sodanige riglyne verskaf vanuit ' $n$ dogmaties-etiese perspektief. Die klem val nie op berading of die eksegese van bepaalde Skrifgedeeltes nie, maar op relevante bybelse beginsels rakende hierdie onderwerp. Dit beteken egter nie dat Skrifverwysings geïgnoreer kan word nie. Dit spreek vanself dat bybelse beginsels afgelei moet word van bepaalde skrifgedeeltes, waarmee dan op 'n verantwoordelike wyse omgegaan moet word. Dit beteken onder andere dat konteks en historiese agtergrond belangrik is. Bybelse beginsels sal egter nie net as riglyne geïdentifiseer word in die evaluering van saambly nie, maar ook as logiese beginsels in die toepassing daarvan. Om dit te bereik is probleme ten opsigte van saambly geïdentifiseer en opgevolg met 'n bybelse perspektief oor wat 'n ware huwelik eintlik werklik behels en inhou.

\section{Introduction}

The different values and attitudes regarding relationships and sexuality maintained in the same culture and family are remarkable. It often result in drastic differences between parents and children, and usually cause immense stress and sometimes even separation between them (Noëth 2010:14). It also happens that parents, for the sake of peace, just discard their own views, or approve of the present view of free sex and cohabitation. There are even those parents who participate in this lifestyle.

These different values are certainly not something new. In Christ's conversation with the Samaritan woman, it seems that she was involved in a cohabitating relationship. Jesus said: 'The fact is, you have had five husbands, and the man you now have is not your husband' (Jn 4:18). This lifestyle was especially propagated during the 1960s and 1970s with rock ' $n$ ' roll, hippies and the playboy ideology. However, in our present society these views have increased in popularity, and the pendulum still swings in the same direction. This is also true in most Western societies: 'Since the 1970s the incidence of cohabitation has increased sharply in many Western societies. In Britain, for example, cohabitation before marriage had become the majority practice by 1992' 
(Jenkins 1995:238). Nevertheless, with each extreme view and lifestyle there are negative consequences for individuals as well as for all of society.

Unfortunately most Christians find it difficult to give account of the biblical view in this regard. The result is that they submit to peer pressure, or just give way to their own desires. After all, we live in a world where television programmes promote it, commercials advertise it, Hollywood glamorises it, parents tolerate it, and churches ignore it - what a combination! In terms of the media Hager declares:

One of the greatest factors appears to be the media. The average teen watches twenty-three hours of television per week. As Proverbs 23:7 says, 'For as he thinks in his heart, so is he.' If inappropriate information is fed into the brain, then inappropriate responses will result. If young people are exposed to sexual explicit types of behavior via the media, they are more likely to act out that behavior. (Hagar 2000:209)

Instead of changing, many believers try to reconcile their lifestyle of free sex and cohabitation with the Christian faith. It is usually done by rationalising and justifying it, or by trying to convince others that their behaviour is acceptable and appropriate before God. Schenck (1999:55) rightfully declares that such behaviour boils down to a disregard of the third commandment: 'You shall not misuse the name of the Lord your God, for the Lord will not hold anyone guiltless who misuses his name' (Ex 20:7). He explains that when we claim God's approval about something that is clearly not his will, or when we claim his direction for something that is of our own making, we actually misrepresent Him and take his name in vain. We illegitimately lend the imprimatur of God's good name to something that is not good, which is tantamount to a fraudulent claim endorsement.

Accordingly, this issue has become an increasing crisis in our society. Research (Van Wyk 2009:85) also indicates that the majority of cases of cohabitation originated from a background of broken families. In South Africa 64\% of first marriages end up in divorce, $82 \%$ of second marriages, and $91 \%$ of a third marriage. Cohabitation seems to be a symptom of deeper problems (mainly man's relationship with God and broken families), and these issues need urgent attention.

More so, because most preachers remain silent and do not give church members clear biblical direction. Usually they remain silent out of fear that certain members (sometimes prominent members) will take acceptance against such preaching. Their silence, however, seems to cause many people's lives to be dominated by anxiety, feelings of guilt, sin and confusion.

The silence of the church correlates of course with the popular and also secular view that we should not be judgmental in this regard. If, however, it is maintained that an individual has the right to determine his or her own moral standards, and other people or the Bible has no right to condemn them, then also the church has no right to say anything about cohabitation. Sometimes the church does not even have anything to say about it!

It will be a sad day if the church looses its prophetic message. Such a church will, from a biblical perspective, be irrelevant to society (Vorster 2010:9). The church has a message that does not only speak of God's grace, but also of his condemnation. If this is no longer the case, then the church has reached a situation as described by Paul in 2 Timothy 4 :

For the time will come when men will not put up with sound doctrine. Instead, to suit their own desires, they will gather around them a great number of teachers to say what their itching ears want to hear. They will turn their ears away from truth and turn aside to myths. (vv. 3-4)

This does not mean that the application of biblical principles as such can solve the problem. The biblical message should always be communicated in love and understanding (Noëth 2010:15). Nevertheless, principles alone cannot really change a person's life. Therefore, the emphasis should not only be on what the bible says, but also on why the Bible says it. And even that is not enough. Biblical principles concerning morality presuppose a loving relationship with God. Without such a relationship no profound change is possible. Obeying biblical principles should always be the result of a relationship with God, and not something that is done coercively.

Christian couples that cohabitate, experience conflict in their relationship with God, or are in general careless about it, they do not really love Him (Noëth 2010:15). This carelessness and lack of love for God is in fact at the core of their problem. Jesus said in John 14:

If anyone loves me, he will obey my teaching. My Father will love him, and we will come to him and make our home with him. He who does not love me will not obey my teaching. These words you hear are not my own; they belong to the Father who sent me. (vv. 23-24)

\section{The message and outcome of cohabitation}

Cohabitation refers in this context to an unmarried couple that lives together like a married couple. The motive in doing so is usually to make absolutely sure that they are compatible before they engage in marriage. It is also possible that they do not foresee any marriage at all and reject this institution completely. In such cases cohabitation is seen as an experiment to test their compatibility to be a couple - and if they are still young, to determine whether it is suitable for them to have children or not.

Cohabitation has become socially acceptable (even amongst some Christians) although it is contrary to the most fundamental teachings of the Christian faith. This acceptance is reflected in the way we have changed our language in this regard. Flanigan and Williams (2011) point out that the term partner is presently used without any differentiation between cohabiting partners and married partners. 
Nevertheless, to see cohabitation as an alternative for marriage is a total misconception of what marriage is all about. A couple that makes a marital commitment, does so with the full understanding that they have chosen each other completely, and with the intention to engage in a lifelong relationship. Against this, cohabiters keep from the very start, a back door open to make sure that there is always a convenient escape route if things do not work out between them.

Hereby it is not denied that divorce can also be seen as an escape route for married couples. However, in the case of cohabiting couples, separation is much easier in terms of responsibilities towards each other, and the possibility of such a separation, in contrast to marriage, is part of the relationship from the very beginning. It is therefore a relationship in which they have not chosen each other completely.

A valid question is: Is cohabitation still not a better option than marriage? Is it not better to have an open backdoor, and to make sure that the relationship will indeed be a success? In theory it sounds good and logical, but in practice it is not the case. There are certain reasons for that. The following three are important:

\section{Conflicting communication}

A cohabiting couple communicates to each other a double and conflicting message. It is a way of communication that is very confusing. The classic example is that of the mother who says to her child: 'I've told you a million times, never exaggerate!' Such a double and conflicting message is also communicated when a parent says something but does the opposite. After all, one does not only communicate with words, but also with one's deeds. Therefore, to forbid your child to lie, but then do it your self, is a further example of double and conflicting communication. In fact, non-verbal communication speaks with more authority than words. Your behaviour and deeds are more credible than that what you say.

Hillerstrom (2004:43-44) shows that cohabitating couples communicate non-verbal conflicting messages to each other every day. When a man and woman decide to live together like a married couple, they say:

I desire physical and spiritual intimacy with you. I would like to know you deeply. I want to be one with you. Only by living together you will enable me to come close to you and to express my love for you.

Picture them with open arms approaching each other.

But there is also a second message. This message speaks of the fact that they are not willing to make a marital commitment:

I do not really want to commit myself to you. Don't come too close; there are limits. I don't want to get so close to you that I can't escape if you hurt me. I am not sure whether I can trust you. I do not choose you completely.
Picture them with open arms slowly retreating from each other.

The message is:

You have to understand that I really feel for you and that I love you, but I am not sure if I can trust you with my deepest feelings. You did not convince me to marry you. Maybe there is someone else better for me. You did not yet convince me that you would always love me, so I want to give you a chance and time to prove it to me. If it does not bother me to stay with you, then we might get into a lifelong commitment, but there are no guarantees. Our living together is just a test to see whether we are really compatible. If you do not make it, I am going to leave you.

Their relationship is therefore built upon judgment and achievement. The way my partner behaves will determine whether a lifelong relationship will develop or not. 'It is just a trial run. "If you fail, I will leave"' (Hillerstrom 2004:51).

Against this, marital couples communicate only one message:

I choose you in such a way that I want to make a marriage commitment. I would like to be one with you for the rest of my life. I am aware that conflict and strife might come, but I am willing to work through these things and to stay with you. Judgment and achievement is not the basis of our relationship, but my commitment to you and the determination to make it work. I am willing to trust you with my deepest feelings and to open my heart to you. I will love you unconditionally.

It stands to reason that such a commitment asks for dedication and sacrifices, and there is a determination to make it work.

The outcome of the double and conflicting message that is communicated by cohabiters is that a lack of trust is from the beginning part of their relationship. That which is true and not true is unclear. That which is said and that which is lived, are two separate things. They live with the uncertainty of: 'Am I your only love or not? Do you want to become one with me or not? Have you been committed to me or not?' An integration of mistrust and doubt is rooted at the core of their relationship. When a couple gets married they say yes to each other, but in a cohabitation relationship they say probably to each other (Vorster 2010:10). The probability that such a relationship will last for life is obviously small.

To marry eventually, might be the cause that this built-in mistrust and doubt is overcome. Yet they start their marriage with arrears. It seems that those who were involved in a cohabiting relationship and get married later, are more inclined to divorce than those who did not cohabit before marriage (Van Wyk 2009:87). Some research concluded that the risk of divorce is $80 \%$ higher amongst those who cohabit before marriage, over against those who never cohabit (Botha 2003:204). One reason for this is that the easy escape route and the open backdoor that were so part of their relationship, are now closed. It is always difficult to get rid of something that was an integral part of a relationship.

After marriage such couples feel the anguish of being constrained. This is the result of the lack of commitment that was always part of their relationship, but is know accentuated 
by a marital commitment. Mistrust and doubt have been such a part of their relationship that it now becomes very difficult to be freed from it. Their relationship requires extra help, counselling and hard work to make it successful. If not, the chances are good that their marriage (just like cohabitation) will end in separation.

Trust and commitment are from the beginning part of a healthy marriage, irrespective of emotions and the high and low tides that will come. Trust and commitment are not ingredients added later to the relationship as in the case of those who first cohabited and later got married, it is promised to each other from the beginning of their marriage.

\section{Adjustment problems}

In all marriages couples are confronted with problems of adjustment. This is because two people with different backgrounds, personalities and education are now, through marriage, compelled to live close to one another. To them it is a new experience that they were not used to. It demands constant dedication and motivation to work through these adjustment problems. A marital commitment is however a strong incentive to do so.

In fact, one of the basic goals of marriage is to address and solve the differences that might come between them in order to have a good relationship. It is not always that easy and sometimes the help of a counsellor is needed. The point, however, is that married couples make, due to their commitment to one another, an effort to deal consciously with these differences. No couple marries with the expectation that their marriage will only last for a year or two, otherwise they would not even consider getting married. It is important to them that their relationship should be maintained for life.

Cohabiting couples do not live with the same expectation or motivation to make the relationship work, as is the case with married couples. Cohabitation is seen as the easiest way to immediately participate in the privileges of marriage without any hard work concerning the relationship. In our broken society, hard work is always necessary for good and healthy relationships. Whenever you talk to married couples that have purposefully worked on their relationship with all the accompanying problems, they will unanimously tell you that all their hard work was worth it over and over again. For everything in life the principle counts, especially in a lifelong relationship, that your input determines what you are going to get out of it. You cannot reap what you have not sown, and most cohabiting couples do not understand this principle.

Some research (Hillerstrom 2004:42) shows that only $30 \%-40 \%$ of cohabiters marry eventually, and that most cohabiting relationships do not last for more than two years. The result is that cohabiting partners foresee, in contrast to married couples, a short-time relationship.

This approach of 'I am not really committed to you', gives rise to an attitude where adjustment problems are not really dealt with. An example of such an attitude might be: 'He is untidy and will rather watch sport on TV than maintaining their living place. If you get tired of it, you can leave. It is no big deal.' On the other hand:

She is not always considerate, and will invite friends without asking him, or being involved in her own interests, without taking care of his needs. It is however not that serious, since your focus is on 'real problems'.

Besides, most frustrations can be solved in bed, tomorrow everything will be fine again.

Most differences and irritations are usually pushed to the side, without really dealing with them. If the differences become too much, and the irritation level gets too high, you just take your things and leave. One should remember, however, that although the relationship did not last for long, no one will escape the hurt and pain that accompany a separation. The separation is also experienced as a failure that often affects a person's self-image negatively.

Yet, if the couple decides to marry, they again start with arrears. The idea of living together was to test the relationship by looking thoroughly into all the differences and irritations, but in reality they were dealt with only superficially. It is also very difficult to open your heart to someone in a relationship that is seen as an experiment and will most probably last only for a while (Möller 2000:30). Cohabiters gradually fall into the habit of ignoring and suppressing adjustment problems.

If they had gotten married they would have been compelled to deal with these differences and irritations. The backdoor is closed. Their relationship already has started to grow into a direction where they got used to not deal with these problems, with the result that they, now as a married couple, experience these differences and irritations very intensely. The emotional impact of these things changed and could be devastating. In a healthy marital relationship the emotional reaction is usually: 'It bothers me.' But in this situation the reaction is: 'You were not honest with me when we stayed together. You pretended to be what you're not. You have deceived and betrayed me!' This reaction of course is an exaggeration of the real situation, but as a result of a lifestyle where these problems were ignored and emotions suppressed, both partners become too intensely irritated to deal with them (Hillerstrom 2004:46).

It stands to reason that these feelings of being deceived and betrayed will intensify their experience of differences and irritations. It triggers frequent conflict that often becomes explosive. Partners become each other's adversaries, cooperation becomes competition and vulnerability becomes self-protection (Hillerstrom 2004:46). It is clear that there is no such thing as a trial marriage. To try to experience marriage without real commitment to each other is an illusion and to the detriment of a marriage that may follow:

It is ironic that many people opt for cohabitation as a trial for marriage because the one thing that you cannot have a trial for is a permanent relationship such as marriage. (Jenkins 1995:238) 


\section{Marriage became old fashioned}

There are those who live together because they believe that marriage became old-fashioned and irrelevant in our present society (Louw 1985:7). It is true that many things have changed, but God did not (Heb 13:8), and neither his institution of marriage. To strengthen their argument, cohabiting couples sometimes say that marriage is restrictive and oppressive, limiting their freedom to come to selfrealisation. Marriage is seen as a means of reinforcing sexual stereotypes (sex is restricted to married couples) and women are exploited by being taught to be submissive to their husbands. These are things that cannot be tolerated anymore.

In contrast to this, cohabitation is seen as a means to enable couples to live together without the restrictions imposed on them by outdated marital regulations and vows. An essential aim of cohabitation is to give each partner the opportunity to come to maximum self-realisation. After all, cohabitation is socially acceptable and convenient. When one or both partners are no longer satisfied with their relationship, they have the liberty to seek self-fulfilment elsewhere. However, although cohabitation appears to be freer than marriage 'the freedom to leave introduces fear into the relationship. Fear is destructive of real freedom, which grows best in the security of a loving, committed, permanent relationship' (Jenkins 1995:238).

These ideas about marriage have their origin in a misconception of what a marriage really comprises. The problem is not with marriage as such, but with the people involved in the marriage (Botha 2003:204). The fact that people have misconceptions about marriage and also misuse it does not mean that marriage is outdated or bad. The real problem is that married couples are not well enough informed or just indifferent concerning God's expectations and principles in this regard. A marriage, in which God's principles are ignored causes many troubles and is not a marriage in the real sense of the word.

Because of a lack of information, cohabitation is seen as another form of marriage. It differs only in name and in socalled restrictions. Furthermore, many people see no purpose in an expensive marriage ceremony and attach little value to a marriage certificate. The question is: What difference can a marriage certificate make?

All these negative connotations attached to marriage can only be dealt with if we are willing to listen to what God says about it, and then weigh the biblical views up against the main beliefs concerning cohabitation. What God expects from marriage is a theme on its own with many aspects, consequences and principles. I therefore want to restrict myself to only that which constitutes and grounds a marriage.

\section{What constitutes a marriage over against cohabitation?}

To understand what is fundamental to marriage and what constitutes it, we have to go back to those principles of scripture when God instituted marriage. This foundation is laid in mainly two references from the book of Genesis (other scriptures in this regard will be dealt with later).

Genesis 1:

So God created man in his own image, in the image of God he created him; male and female He created them. God blessed them and said to them: Be fruitful and increase in number ... (vv. 27-28)

Also Genesis 2:24: 'For this reason a man will leave his father and mother and be united to his wife, and they will become one flesh.'

In the New Testament Jesus also referred to these verses in order to emphasise what is fundamental to marriage. We read in Matthew 19:

'Haven't you read', he replied, 'that in the beginning the Creator made them male and female' and said, 'For this reason a man will leave his father and mother and be united to his wife, and the two will become one flesh?' So they are no longer two, but one. Therefore what God has joined together, let man not separate. (vv. 4-6)

\section{To his own image; male and female He created them}

The image of God is amongst other things, also realised in the relationship between man and woman. This relationship finds its climax in a marriage that reflects something of the image of God in the sense that the love, closeness, peace and harmony that exist between the Father, Son and Holy Spirit are mirrored in the relationship of the husband and wife:

We are created in this image, to live with the qualities that mark the Trinity: love, intimacy and community. This is why it was not good for the man to be alone. In his aloneness, he didn't mirror the image of the triune God. (Stanton \& Maier 2005:173)

Marriage is therefore particularly healing in a society where lovelessness, loneliness, stress and separation are causing so much grief and pain.

In this bond of one man and one woman, in a heterosexual relationship, God's image is expressed further by the fertility of man and woman, and the accompanying potential to beget children. After all, children and parenthood reflect also something of the image of God as realised in the relationship between God the Father and his Son Jesus Christ.

The more the image of God is realised in a person's life, the more a person becomes what God intended him or her to be. It is something that cannot be separated from God's love for us. It is a love in which God grants us to experience more and more of who He is, and in this process He also uses marriage and family as instruments to realise it. This makes marriage and family an exercise field to develop into a direction where God can restore his image in our lives. To be like God means in the first instance that true love, as realised in the ultimate marriage between Christ and his bride (the church), is also realised in the lives of married couples. That is also true in the relationship between parents and children as seen in the relationship between the Father and his Son Jesus Christ. In other words, marriage and family receive from God an eternal dimension. 
This deeper meaning of the husband-wife relationship is totally missed in a cohabiting relationship. It is a shallow relationship with no eternal dimension at all. It is a relationship that is built upon own satisfaction and fulfilment, and therefore egocentric in nature. God's given goal of marriage is missed and the focus is on what I can get out of the relationship rather than on what I can give (Van Wyk 2009:85). Almost nothing of spiritual intimacy actualises, and therefore the image of God, in terms of the relationship between Father, Son and Holy Spirit, is not reflected. In fact, a lack of spiritual intimacy enhances loneliness and separation within a relationship.

Cohabitation is furthermore not directed to the eternal marriage between Christ and his bride, it is in a dead end with almost no meaning. It is not an exercise field like marriage, in which man is prepared for eternity. It is therefore not instrumental in God's hands to help man to be restored to his image and to (different from animals) transcend that which is transient and mundane. We should realise that if a person's life lacks eternal values, he or she will increasingly be confronted with the meaningless and emptiness of such a life.

Friendship relationships help unmarried people to experience something of that which is pre-eminently experienced in a married relationship. Contrary to this, cohabitation is not a friendship relationship as realised in marriage or in general. It cannot be a marriage-friendship because there is no marriage, and friendship out of wedlock respects the other person's privacy and space, whilst this is not done in cohabiting relationships. They are sexually together, they claim each other's space and want to share in the privileges of a marriage-friendship without any commitment. Such intimacy does not enhance friendship, but rather destroys it it is an inherent contradictory. They overstep the boundaries of friendship and simultaneously push one another away (no commitment).

As far as a family is concerned, cohabiters are in general hesitant to have children. Research shows for example, that abortion on demand is much higher amongst women who are in a cohabiting relationship than in a married one (Ambert 2005:2). This is due to the uncertainty of their relationship, and the risk to become a single parent. Most women are obviously not prepared to take such a risk. Reproduction is part of God's plan with marriage, but for cohabiters such an idea is couched in uncertainty and threat. This uncertainty and threat might be transferred to a later marriage, so that they decide not to have any children at all.

\section{A man will leave his father and mother and be united to his wife}

The statement that a man should leave his father and mother and be united to his wife is a clear indication that God instituted marriage. It is not a cultural institution. Therefore, leaving your family to establish another is at the heart of marriage:
Women help men become what they are created to be, and men help women become what they are created to be. To deny this is to deny our full, God-given humanity. Men and women need each other, and marriage is where we most fully and completely come together. (Stanton \& Maier 2005:173-174)

Flanagan and Williams (2011) emphasise the fact that when a husband and wife are united in marriage, it is also something that becomes known to the rest of the family and friends. It is a public event that is solemnised before witnesses, and therefore others in society are involved.

The message is clear, they have committed themselves to each other by pledging certain vows, and are no longer available to anyone else:

Though vows are not explicitly mentioned in Scripture, they are implicit in the idea of 'cleave' or be 'united'. Wedding vows have two functions: 1) to define the nature of the relationship; and 2) to declare future intent. Whilst marriage is a commitment for the future as well as for the present, cohabitation tends to be a relationship just for the present with the future left deliberately open-ended. (Jenkins 1995:238)

Marriage is therefore a commitment that is made regardless of what conflict or stress may develop. In most aspects of the relationship it is no longer about me but about us deciding, feeling, planning and living a particular lifestyle (Möller 2000:14). This is the secure environment into which children are later born, nurtured and allowed to grow up as adults.

Opposed to this, cohabitation is a private agreement between a man and woman, which often disregards the wishes of the other. No public vows of commitment are made, and no witnesses are involved. In other words, uncertainty regarding the permanency of the relationship is from the beginning part of it. It is expected that the relationship will not last for long, and it offers least of all a safe and stable environment into which children can be born or reared.

\section{He will be united to his wife, and they will become one flesh}

When Christ referred to Genesis $2: 24$ '... be united to his wife, and they will become one flesh ...' His conclusion was: Matthew 19:6 '... So they are no longer two, but one.' To be one flesh refers to physical or sexual unity between husband and wife, but it is also more than that. The sexual relationship between man and woman is placed in a broader framework, the unity of marriage - be united to his wife. He is first united to his wife (spiritually), and then they become one flesh. A sexual relationship does not really bring unity; it rather presupposes unity. It is a celebration of the unity that already exists, and through sexuality this unity is accentuated and made more intense.

The biblical view of marriage is that husband and wife should be one spiritually and physically, and that physical unity should realise in the context of spiritual unity. Heyns (1986:160) accentuates that in this unity, faithful love [liefdestrou] should be seen as the highest norm in their relationship. After all, marriage that presupposes oneness and 
faithfulness between a man and a woman is still a marriage even if there may for some reason be no sexual intimacy (sickness, biological problems, impotency, aging, etc.). It is not sexuality as such, but marriage (and the accompanying commitment, love and faithfulness) that makes them one so that they are no longer two, but one person.

In a cohabiting relationship there exists an indifference regarding sexuality. It is acceptable for them to have a sexual relationship without true spiritual unity and commitment:

Sex without a lifelong commitment violates the inner reality of the act; it is wrong because unmarried people thereby engage in life-uniting acts without a life-uniting intent. (Jenkins 1995:238)

Their sexual relationship is not a celebration of the unity that already exists, but is primarily directed to own pleasure and fulfilment.

However, the more sexuality is separated from spiritual unity and commitment, the more it is being degraded to the level of functionality (Thielicke 1964:24). This makes a cohabiting partner unlimitedly exchangeable, there will always be another person who can fulfil my sexual desires (functionality) in a better way. In fact, to have a sexual relationship without spiritual unity is to lower this gift of God to something physical with no spiritual meaning (Vorster 2010:11).

Sexual infidelity is therefore common amongst cohabiters, and the fact that the duration of the relationship is relatively short, and possibly followed by other similar relationships, sexual diseases are transmitted with very negative consequences (Hagar 2000:211-213). After all, to be treated like a used article (functional), causes inevitably estrangement. It is not surprising that many cohabiting partners are being left as soon as the woman becomes pregnant. The functional value of the man's partner has become low.

Marital love between husband and wife that includes spiritual unity and commitment is in fact an event where God grants the couple to experience something of the unity between Father, Son and Holy Spirit, as it has already said. It is also in the context of the Trinity that we become children of God. After all, children of God would be extremely confused and uncertain in their relationship with God, if there were no unity and commitment between the Father, Son and Holy Spirit, even if every person of the Godhead assures us of his love. Without true unity in the Godhead, we as children will feel insecure and unsafe in our relationship with God. Therefore, married couples that are really spiritually one, project an exceptional feeling of security and safeness to their children. For example, four times the Lord prayed in John 17 for believers to become one as the Father, Son and Holy Spirit is one. How much more is this true for a marital relationship!

Cohabiting couples do not communicate this unity to their children. Even if both parents declare their love for them, they still feel unsafe, as true unity is lacking between their parents.
It is for example shown that anxiety and depression are $50 \%$ higher amongst children living with cohabiting parents than in those who are reared in the context of a marriage. The anxiety and depression escalate dramatically if the mother's partner changes several times (Ambert 2005:2).

The unity between husband and wife is further symbolised by the habit of the wife to take the surname of her husband. Therefore, the children who are born out of that marriage are known by that name, it becomes the family name. By this they also become part of a bigger family, with many relationships.

In a cohabiting agreement this unity is not recognised and man and woman keep their surnames. By this they accentuate the fact that they have remained two separate individuals. No new family relationships are established (father- or motheror son- or daughter-in-law), and the wishes and desires of parents and other family are usually ignored. It again accentuates the self-centred nature of such relationships.

\section{Cohabitation and the law}

A marriage certificate refers to the fact that a man and a woman are lawfully married. This legal aspect of marriage is also found in the Bible. The couple and the parents from both sides, made an agreement together concerning the future marital commitment (Möller 2000:5). This was a legal agreement that laid certain responsibilities on both the parents and the couple. For example, marriage was seen as an agreement or covenant between man and wife that involved absolute faithfulness as implied in Proverbs 2:17, Ezekiel 16:8 and Malachi 2:15-16. It also meant that the couple was married in public to ensure that there could be no doubt that the man and the woman were lawfully wed (Jdg 14:1-20; Jn 2:1-12).

In the New Testament marriage receives further meaning. It is seen as much more than a mere transaction between a man and a woman (Vorster 2010:11). In Ephesians 5:22-33 it is said that the relationship is built upon the relationship between Christ and his church and presupposes mutual and unconditional love for one another. The different roles of husband and wife are stipulated and in 1 Corinthians 7:5 Paul says that a couple should not refuse sexual intimacy because it might lead to temptations and a lack of self-control.

These responsibilities also meant that the husband could not easily divorce his wife. Divorce could only be realised if it was confirmed by a legal document. After all, a legal relationship can only be broken by another legal regulation. Here the Bible refers to a letter of divorce that should be handed to the wife in case of marital separation (Dt 24:1; Mt 19:7). It was a letter that was compiled and approved by the elders who divorced the couple legally from each other.

Therefore, marriage has according to the Bible, a religious as well as a legal aspect that should be honoured. It is something that corresponds with Paul's pronouncements in Romans 13: 
Everyone must summit himself to the governing authorities, for there is no authority except that which God has established. The authorities that exist have been established by God. Consequently, he who rebels against authority is rebelling against what God has instituted, and those who do so will bring judgment on themselves. (vv. 1-2)

In the same chapter Paul further says:

For he is God's servant to do you good. But if you do wrong, be afraid, for he does not bear the sword for nothing. He is God's servant, an agent of wrath to bring punishment on the wrongdoer. Therefore, it is necessary to submit to the authorities, not only because of possible punishment but also because of conscience. (vv. 4-5)

The legal aspect of marriage is indeed to our benefit and exists to protect husband and wife against that which may threaten their relationship, for example violence, divorce and death. The idea that a piece of paper (marriage certificate) can make no difference to the relationship is therefore without any ground.

In the South African law (Bergman 2010) there is no indication that a cohabiting relationship equals a marriage, irrespective of the duration of the relationship. The partners are not seen as a married couple. This means that if the relationship is broken, there is no law to protect those involved in terms of their assets. It will ask for a court case to prove a universal partnership between them before the division of assets is seen as common property.

Cohabiters are therefore to a great extent unprotected by law. The legal implications for such couples are always to their detriment, and particularly to the woman who is usually left with no assets or support in cases of separation. A cohabiting agreement is made at their own risk (Bergman 2010).

\section{The dangers concerning cohabitation}

Some research has already been conducted in terms of the outcomes concerning cohabitation, as well as the effect it has on the children involved. Anne-Marie Ambert (2005:2) has made a study of the results of many research papers that examined the social, emotional and financial effects of cohabitation and marriage on men, woman, children and society. Some of the outcomes are as follows:

- Some individuals choose cohabitation because it does not require sexual fidelity. Evidence indicates that the experience of a less committed cohabitation shapes subsequent marital behaviour.

- Some couples continue to live their marriage through the perspective of the insecurity, lack of pooling of resources, low commitment level, and even lack of fidelity of their prior cohabitation.

- Married couples that previously lived together are less faithful in their sexual lives. And a lack of fidelity is known to be a factor leading to higher rates of marriage breakdown.

- Married couples that had cohabitated had less positive problem-solving behaviours and were, on average, less supportive of each other than those who had not cohabited.
- Couples who had cohabited before marriage had much higher rates of premarital violence than those who had not lived together. This premarital violence then lead to higher rates of marital violence, another factor related to divorce.

- Those who cohabit are generally more approving of divorce as a solution to marital problems.

- Couples who cohabit are less religious than those who marry without prior cohabitation. On this point there are several studies that indicate a correlation between religiosity and marital happiness as well as stability.

- A propensity to cohabit soon after starting a romantic relationship leads to a pattern of instability. People who go through a series of de facto relationships are more likely to contract quick marriages, which are harder to remain faithful to.

- A risk factor with cohabitation is its unstable nature. Most unions dissolve within five years.

- In the United States an estimated $40 \%$ of all children will live with their single mother (never-married or divorced) and her boyfriend at some point before their 16th birthday.

- For children, cohabitation means a greater risk of living within an unstable family structure, especially when their mother cohabits with a man who is not their father. Such children have lower school performance and more behavioural problems.

- Cohabitation affects the mother's capacity to give adequate attention to children, and contributes to general neglect. The mother's partner is not likely to compensate for this deficiency because his attachment to the children is often low.

- Physical abuse is also more likely and young children in cohabiting relationships are more likely to be injured or killed by their mother's live-in boyfriend than in biological families. Girls, for their part, are at higher risk of being sexually abused.

- Commitment and stability are at the core of children's needs: yet, in a great proportion of cohabitations, these two requirements are absent.

At the end of her study, Ambert notes, that many people maintain that marriage is merely a matter of lifestyle choice and that it is equivalent to cohabitation, but most research rejects this point of view. Marriage is in fact to the benefit for both spouses and children. Lawmakers should take these outcomes into consideration.

\section{Conclusion}

Research supports the view that the escalation of cohabitation has extremely negative consequences on character development, relationships and the basic structures of society. Parents, young people and children are in general uninformed concerning the dangers involved in cohabitation. This lack of knowledge results in a situation where the whole issue of cohabitation is not really communicated amongst parents and children. This leads to a situation where arguments concerning free sex and cohabitation are mainly dealt with on an emotional level that triggers much conflict and separation. 
To be informed, to know and to be able to communicate all the consequences of cohabitation is therefore urgent. To tell the truth about cohabitation is of course not always the popular route to follow. Cohabitants do not always want to hear the truth, but as Adams (1973) puts it:

Of course the truth hurts, but it never hurts like a lie. Sin always causes pain and misery. But repentance leads to peace. When you tell the truth, the hurt comes quickly, but healing soon follows. If you put off telling the truth, you will suffer longer and in the end suffer the pain of facing it after all. When one wrongly handles the truth, it really hurts. (p. 396)

However, telling the truth is not enough. Sin and disobedience to God's principles are not overcome by good argumentation or logic. Sin is an adventure on its own, it has a fascination and stubbornness that ignores all good argumentation, logic and truth. Paul for example, wrote to the Galatians who had turned from the way of truth and said: 'You foolish Galatians! Who has bewitched you?' (Gal 3:1).

At the core of this ethical problem is a person's relationship with God:

Taken as a whole, biblical morality is so closely related to the worship of one sovereign and righteous God that the biblical writers seldom distinguish clearly between ethics and faith or between ethics and religion. Throughout the Scriptures morality is rooted in religious faith. (Gardner 1975:229)

The church has to enable its members to help unbelieving children, parents, family and friends to accept Christ as Lord, and to assist them in a continuous relationship with God. Moral issues, like cohabitation, can only be addressed and conquered from this basis.

\section{References}

Adams, J.E., 1973, The Christian counselor's manual, Baker Book House, Grand Rapids, Michigan.

Ambert, A., 2005, 'Cohabitation: A recipe for marital ruin', Zenith Daily Dispatch, 17 September, n.p.

Bergman, R., 2010, Rights of cohabitants, viewed 10 January 2011, from http://www. law24.com/Roy+Berbman/1062 cohabitatio.html

Botha, A., 2003, 'Saambly?', in H. Stander (ed.), Wat die bybel sê oor, Carpe Deim Media, Vanderbijlpark.

Flanagan, D. \& Williams, E.S., 2011, Cohabitation or marriage, viewed 07 January 2011, from http://www.belmonthouse.co.uk/Marriage,\%20cohab\%20and\%20 divorce/cohabitation.htm

Gardner, E.C., 1975, s.v. 'New Testament Ethics', in J. Macquarrie (ed.), A Dictionary of Christian Ethics, Flechter \& Son Ltd, Norwich, pp. 229-232.

Hagar, W.D., 2000, 'Casualties of the sexual revolution', in J.F. Kilner, P.C. Cunningham \& W.D. Hagar (eds.), Youth risk takers, The reproduction revolution, A Christian appraisal of sexuality, reproductive technologies, and the family, pp. 205-229, William B. Eerdmans Publishing Company, Grand Rapids, Michigan.

Heyns, J.A., 1986, Teologiese Etiek, deel 2, NG Kerkboekhandel, Pretoria.

Hillerstrom, P.R., 2004, The intimacy cover-up, Kregel Publications, Grand Rapids, Michigan.

Jenkins, G.J., 1995, s.v. 'Cohabitation', in D.J. Atkinson \& D.H. Field (eds.), New dictionary of Christian ethics and pastoral theology, Inter-Varsity Press, Leicester, pp. 238-239.

Louw, D.J., 1985, Die volwasse huwelik, Butterworth, Durban.

Möller, F.P., 2000, Die huwelik, Christelike etiek, vol. 8, Semper Nova Publishers, Johannesburg.

Noëth, J.G., 2010, 'As ons jongmense saamwoon' [When our young people live together], Die Kerkblad 113(3234), 14-15.

Schenck, R.L., 1999, The ten words that will change a nation, Albury Publishing, Tulsa, Oklahoma.

Stanton, G.T. \& Maier, B., 2005, Marriage on trial, Christian Art Publishers, Vereeniging.

Thielicke, H., 1964, The ethics of sex, James Clarke and Co. Ltd., London.

Van Wyk, J., 2009, Kerklike sanksie vir saamwoon? Die 50 grootste geloofsvrae, Carpe Diem Media, Vanderbijlpark.

Vorster, N., 2010, 'Trou of sommer saamwoon?' [Marraige or simply live together?], Die Kerkblad 112(3233), 9-11. 